\title{
AN ANALYTICAL REVIEW OF PUNARNAVA (BOERHAVIA DIFFUSA) WITH RESPECT TO CHAKSHUSHYA PROPERTY.
}

\section{Ayurveda}

\section{Dr. Gavimath Shivanand*}

MS (Ayu) Professor (JSSAMC), PhD Scholar, Department of Post Graduate Studies in Shalakya Tantra, Parul Institute of Ayurveda, Parul University, Waghodia, Vadodara, Gujarat.*Corresponding Author

MS (Shalakya Tantra) Professor and HOD, PhD Guide, Department of Post Graduate

Dr. Rajeev G. Dole Studies in Shalakya Tantra, Parul Institute of Ayurveda, Parul University, Waghodia, Vadodara, Gujarat.

\section{ABSTRACT}

The drugs that perform the best efficacious action in treating specific conditions are categorized in specified ganas. Chakshushya gana dravyas are focused in treating the various conditions of ophthalmic manifestations. Chakshushya dravyas are described in the classical texts of Brihatrayi, Laghutrayi, in particular Bhavaprakasha Nigantu. Yogaratnakara mentioned a group of drugs under the chakshushya varga, Punarnava is one among them. It exhibits various actions along with other Ghataka dravyas, when used in compound formulation. Punarnava is a rich source of many alkaloids, tannins, carbohydrates, saponins, glycosides, proteins, amino acids, phytosterols, phenolic compounds, flavonoids and terpenoids. It is extensively used in the treatment of degenerative disorders including ophthalmic manifestations especially in the treatment of corneal ulcers, conjunctivitis and other eye diseases. Many references are found in the Bhaishajya Ratnavali and Basavaraajeeyam.

\section{KEYWORDS}

Punarnava, Boerhavia Diffusa, Flavonoids, Netrabhishyanda..

\section{INTRODUCTION}

Indian system of medicine 'Ayurveda' is a traditional antiquity and culmination of time, tested concepts of medicine for healthy life. Acharya Charaka explained the entire diseases and a way of life in the form of Trisutra-Ayurveda, Hetu, Linga, Aoushadha. Ashtangayurveda is a systemic division of all 8 specialities, among them Shalakya tantra or Urdwanga chikitsa got its importance in treating ENT, Ophthalmology and diseases of head. The treatment modalities are based on aoushadha, kshara, agni and shastra karma(surgery). The drugs that perform the best efficacious action in treating specific conditions are categorized in specified ganas. Chakshushya gana dravyas are focused in treating the various conditions of ophthalmic manifestations. Chakshushya dravyas are described in the classical texts of Brihatrayi, Laghutrayi, in particular Bhavaprakasha Nigantu.

According to Sushrutha Samhita - "chakshushe hitam chakshushyam" (Dalhana, S.S. 48/132) Yogaratnakara mentioned a group of drugs under the chakshushya varga, Punarnava is one among them. Punarnava is a traditional ayurvedic herb that is used to rejuvenate the whole body. The plant as a whole is used in the treatment of rheumatoid arthritis, fever, edema, eye problems, stomach issues, and liver disorders. The herb Punarnava has 3 distinct tastes mainly Madhura (i.e. sweet), Tikta (i.e. bitter) and Kashaya (i.e. astringent) Rasa. It has Laghu (i.e. light) and Rukhsha Guna (i.e. dry quality) and Ushna Virya (i.e. hot potency). It characterizes Madhura Vipaka (i.e. sweet taste after digestion) and mainly portrays rejuvenating property. ${ }^{1}$

Punarnava (Boerhavia Diffusa) is a perennial spreading herb in various parts of India. It is known for its various actions in treating the diseases. It is exhibits mutravirechaneeya (diuretics), shothahara(antiinflammatary), kasahara(anti-tussive), jwarahara(anti-pyretic), rasayana(rejuvenator), nethrya(beneficial for eye diseases).

Classical review of Punarnava in different SamhitasSushrutha samhita1(a)

\begin{tabular}{|l|l|}
\hline Sushrutha samhita $^{1(a)}$ & 1. Vidarigandhaadi gana \\
& 2. Shaka varga \\
\hline Ashtanga sangraha $^{1(b)}$ & 1. Kasahara mahakashaya \\
& 2. Vayasthapana \\
& 3. Medhya \\
& 4. Rasayana \\
& 5. Shakha varga \\
\hline Bhavaprakasha Nigantu & 1. Malasangrahaka \\
& 2. Sandivatahara \\
& 3. Nethrya \\
\hline
\end{tabular}

\begin{tabular}{|l|l|} 
Sharangadhara samhita $^{1(\mathrm{~d})}$ & 1. Netra- srava \\
& 2. Timira \\
& 3. Adhimantha \\
& 4. Ratryandhya \\
& 5. Netra kandu \\
& 6. Netrya/chakshushya \\
\hline
\end{tabular}

Synonyms- Rakta pushpa, shilatika, shothaghi, kshudra, varshabhu, varshaketu

Punarnava as Chakshushya dravya

Some of the compound preparations having punarnava as an ingredient and used in eye diseases are:

\begin{tabular}{|c|c|c|}
\hline Text & Preparations & Indications \\
\hline \multirow[t]{4}{*}{$\begin{array}{l}\text { Bhaishajya } \\
\text { Ratnavali }^{(2)}\end{array}$} & Nayanasonita Anjana & $\begin{array}{l}\text { Timira, Patala, Netra } \\
\text { Pushpa }\end{array}$ \\
\hline & Nrupavallabha thailam & $\begin{array}{l}\text { Timira, Patala, Kacha, } \\
\text { Nakthandhya, } \\
\text { Arbudha, } \\
\text { Divandhyam, } \\
\text { Linganasha }\end{array}$ \\
\hline & Kanaka thailam & Netra sula \\
\hline & Tapta raja thailam & Netra sula, timira \\
\hline Basavarajeeyam $^{(3)}$ & Karpooradhyajana & $\begin{array}{l}\text { Timira, patala, kacha, } \\
\text { pushpam }\end{array}$ \\
\hline \multirow[t]{2}{*}{$\begin{array}{l}\text { Sharangadhara } \\
\text { samhita }^{(4)(5)}\end{array}$} & Triphala ghrita & $\begin{array}{l}\text { Naktandhya, } \\
\text { nakulandhya, kandu, } \\
\text { pilla, netra srava, } \\
\text { patala, timira and } \\
\text { kacha } \\
\end{array}$ \\
\hline & Punarnava rasakriya & $\begin{array}{l}\text { Punarnava used as } \\
\text { anjana } \\
\text { a. with milk effective } \\
\text { in kandu, } \\
\text { b. with honey- netra } \\
\text { srava, } \\
\text { c. with ghrita- netra } \\
\text { pushpa(corneal } \\
\text { opacity), } \\
\text { d. with oil- visual } \\
\text { disturbance, } \\
\text { e. with kanji- night } \\
\text { blindness. }\end{array}$ \\
\hline
\end{tabular}

\section{Morphology}

Boerhavia diffusa is a perennial creeping weed, prostrate or ascending herb, up to $1 \mathrm{~m}$ long or more, having spreading branches. The stem is prostrate, woody or succulent, cylindrical, often purplish, hairy, and 
thickened at the nodes. Leaves are simple, thick, fleshy, and hairy, arranged in unequal pairs, green and glabrous above and usually white underneath. The shape of the leaves varies considerably - ovateoblong, round, or subcordate at the base and smooth above. Flowers are minute and subcapitate. These are hermaphrodite, pedicellate, and white, pink, or pinkish-red in color. The roots are stout and fusiform with a woody. This trailing herb is mainly collected after rainy season in India

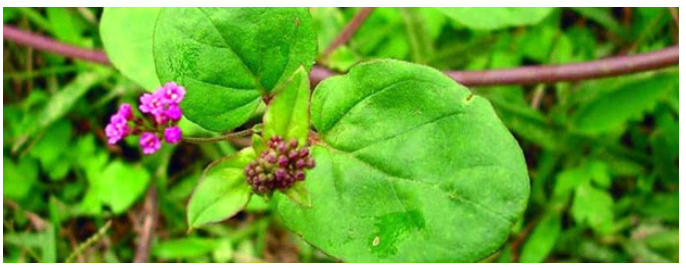

Distribution The genus Boerhaavia has several species, and is distributed in the tropical, subtropical, and temperate regions of the world ${ }^{[6]}$. It is found in Australia, China, Egypt, Pakistan, Sudan, Sri Lanka, South Africa, USA and in several countries of the Middle East. Out of the 40 species of this genus, 6 species are found in India B.diffusa, B.chinensis, B.erecta, B.repens, B.rependa, and B.rubicunda. It is found throughout the warmer parts of the country up to an altitude of $2000 \mathrm{~m}$ in the Himalayan region. It grows well on wastelands and in fields after the rainy season

\section{Chemical constituents of whole plant}

Characterization of the whole plant extract of $\mathrm{B}$. diffusa led to isolation of four new flavonoids and phenol glycosides such as eupalitin 3-O- $\beta$ Dgalactopyranosyl-(1"'2")-O- $\beta$-D-galactopyranoside, 3,3',5-t apiofuranosyl-(1"3')-O- $\beta$-D-glucopyranoside47. Two quinolizidine alkaloids identified as punarnavine I and punarnavine II was isolated from root, stem and leaves. Several volatile compounds were identified in both root and leaves 38 rihydroxy-7-methoxyflavone, 4',7dihydroxy-3'-methylflavone and 3,4-dimethoxyphenyl-1-O- $\beta$-D

\section{Chemical components of Boerhavia diffusa5(a)}

\begin{tabular}{|c|c|}
\hline Class & Compounds \\
\hline Alkaloid & Punarnavine \\
\hline Rotenoids & $\begin{array}{l}\text { Boeravine A-F } \\
\text { Hypoxanthine 9-L-arabinofuranoside } \\
\text { Hentriacontane, } \\
\beta \text {-sitosterol and ursolic acid }\end{array}$ \\
\hline Glycoside & $\begin{array}{l}\text { Punarnavoside } \\
\text { C-methylflavone5,7-dihydroxy-3',4'-dimethoxy- } \\
6,8 \text {-dimethylflavone } \\
\text { 40ß-ecdysone, triacontane } \\
\beta \text {-sitosterol- } \beta \text {-D-glucoside }\end{array}$ \\
\hline Acids & $\begin{array}{l}\text { tetracosanoic, hexacosanoic, stearic, palmitic, } \\
\text { arachidic acids Boerhavin and boerhavic acid }\end{array}$ \\
\hline Lignans & $\begin{array}{l}\text { Liriodendrin } \\
\text { syringaresinol mono- } \beta \text {-D-glucoside } \\
\text { Glycoprotein }\end{array}$ \\
\hline Lipids & $\begin{array}{l}\text { 5-methyleicos-4-ene } \\
\text { Eicos-4-ene } \\
\text { 4-methyloctadec-3-ene } \\
\text { 4-methylnonadecylbenzene }\end{array}$ \\
\hline $\begin{array}{l}\text { Phenolic } \\
\text { compounds }\end{array}$ & $\begin{array}{l}\text { 3,4-dihydroxy-5-methoxycinnamoylrhamnoside } \\
\text { Quercetin 3-O-rhamnosyl }(1 \rightarrow 6) \text { galactoside } \\
\text { (quercetin 3-O-robinobioside) } \\
\text { Quercetin 3-O-(2"-rhamnosyl)-robinobioside } \\
\text { Kaempferol 3-O-(2"'-rhamnosyl)-robinobioside } \\
\text { 3,5,4'-rihydroxy-6,7-dimethoxyflavone 3-O- } \\
\text { galactosyl }(1 \rightarrow 2) \text { glucoside [eupalitin 3-O- } \\
\text { galactosyl }(1 \rightarrow 2) \text { glucoside } \\
\text { jCaffeoyltartaric acid } \\
\text { Kaempferol 3-O-robinobioside } \\
\text { eupalitin 3-O-galactoside } \\
\text { Quercetin } \\
\text { Kaempferol } \\
6,9,11 \text {-Trihydroxy-6a12a-dehydrorotenoid } \\
\text { (coccineone B) }\end{array}$ \\
\hline
\end{tabular}

Some important phyto-chemical constituents and mode of action of Punarnava

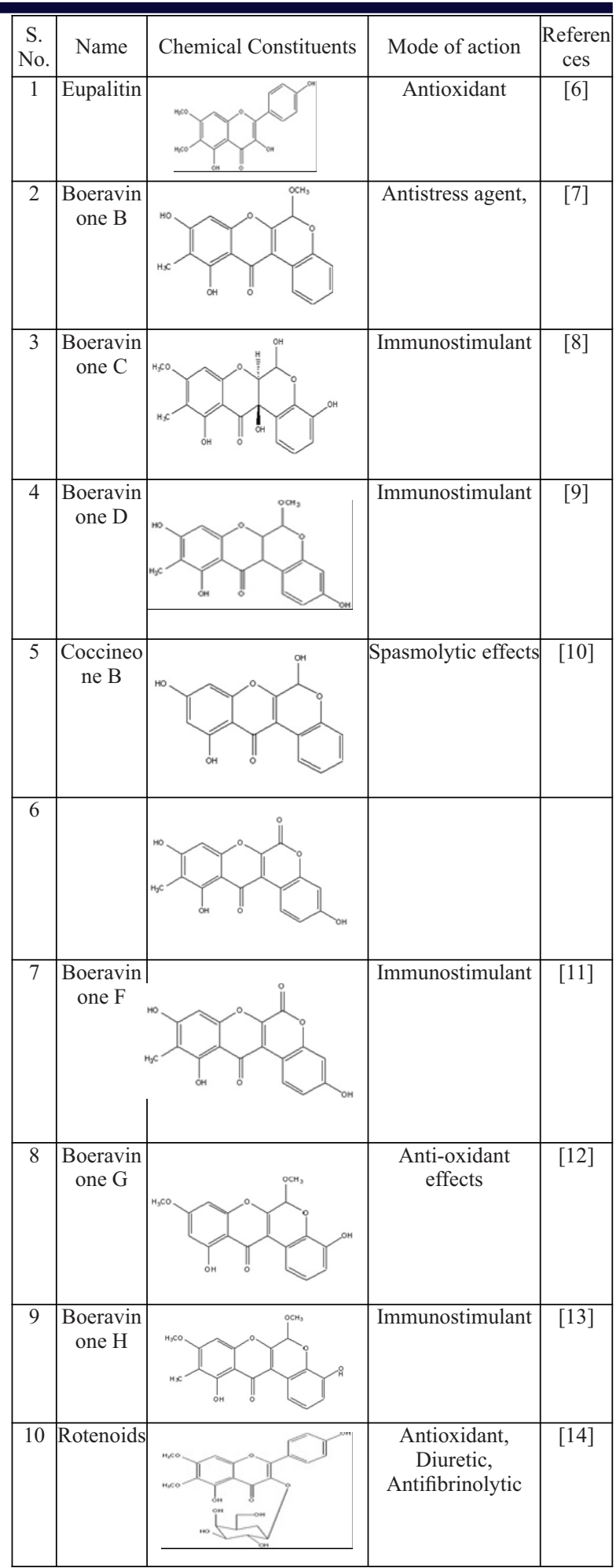

Nutritional Value of Punarnava (100 gms)

\begin{tabular}{|c|c|}
\hline Fat & $1.61 \%$ \\
\hline Sodium & $162 \mathrm{mg}(2.26 \%)$ \\
\hline Vit C & $44.8 \mathrm{mg}$ \\
\hline Calcium & $142 \mathrm{mg}$ \\
\hline Iron & $0.012 \mathrm{mg}$ \\
\hline
\end{tabular}

\section{DISCUSSION}

\section{Punarnava as Chaksushya}

1. Punarnava which is a Rasayana and contains many nutrient materials to rejuvenate the cells of the body. Hence it is one of the Ghataka dravya in many Rasayanas including Chaksushya Rasayanas. 
2. Punarnava is a rich source of many alkaloids, tannins, carbohydrates, saponins, glycosides, proteins, amino acids, phytosterols, phenolic compounds, flavonoids and terpenoids, it is extensively used in the treatment of degenerative disorders including ophthalmic manifestations especially in the treatment of corneal ulcers, Abishyanda and Retinal diseases. Many references are found in the Bhaishajya Ratnavali and Basavaraajeeyam. ${ }^{15}$

3. Boerhavia diffusa (punarnava) root extract exhibits significant anticataract activity in experimental animals. The effect can be attributed to inhibition of oxidative stress. Hence the Acharyas have already advocated this herb in the treatment of Kacha, Timira and Patala.

4. Anti oxidant activity : Oxygen free radicals produced as a result of metabolic process in our body, induce damage to biomembranes and genetic materials leads to many chronic degenerative diseases including night blindness and Retinal degenerative changes.

Beorhavia diffusa play preventive and productive role to maintain the cell survival, cellular interaction and maintenance of cell membranes. Sharangadhara Samhita and Basavaraajeyam have indicated this precious drug in the management of Nakthandhya, Nakulandhya, Timira and Kacha.

5. Anti histaminic activity : Ethanol extract of Beorhavia diffusa linn roots in experimental animals evaluated for anti-histaminic activity. The results are encouraging. Hence Punarnava along with Madhu, or Ksheera Aschotana is indicated in Allergic Conjunctivitis. ${ }^{18}$

6. Punarnava juice extract is used in eyes for topical application. Punarnava leaves extract is used for chronic Opthalmia. Ethanol extract of leaves of Punarnava have exhibited maximum antiinflammatory effect in animal experimentation. Hence it is used for Anjana purpose in the conditions like Netra Srava, Pilla Rogas etc. ${ }^{19}$

7. Nasal drug delivery of the Boerhavia diffusa(punarnava) juice extract is effective in the management of increased intra ocular pressure in chronic simple glaucoma (Adhimantha). experimental studies also focuses upon the significance of nasal route of drug administration in ophthalmic diseases management. Hence punarnava is indicated in dristimandhya wrt adhimantha. ${ }^{20}$ There is a need for further study in this aspect.

8. Punarnava which has got the properties of anticancer, may be an indication for the further study in malignant conditions of eye. Acharyas have mentioned punarnava as a arbudahara.

9. Antibacterial and very high Antiviral activity :The aqueous and ethanolic extracts of B. diffusa leaves had activity on E. coli, S. aureus and $\mathrm{P}$. aeruginosa. The aqueous extracts of large plant materials were prepared and tested in vitro as well as in vivo against phyto-pathogenic viruses on their hypersensitive and systemic hosts. Of the large number of plants screened, Boerhaavia Diffusa root extracts were found to have a broad spectrum and very high antiviral activity. So, Punarnava is effective in many infective eye diseases due to its anti-microbial activity. Hence, in all types of netrabhishyanda, it is an effective herb. ${ }^{21,22}$

10. Punarnava along with Gokshura Basthi is effective in the management of Diabetic retinopathy, and related complications ${ }^{23}$.

\section{CONCLUSION:}

1. Punarnava shows various actions, along with other Ghataka dravyas, when used in different combinations, it is a complete pack of regenerative, antioxidant which is also a Chakshushya dravya explained by Sharangadhara Samhita and Bhavaprakasha Nighantu.

2. Though Punarnava (Boerhavia diffusa) is indicated in various ophthalmic conditions, there is a need to re establish its efficacy with respect to its different actions.

3. Punarnava contains many flavonoids, tannins, alkaloids, vitamins, and antioxidant nutrients which are essential part of Chakshushya property

\section{REFERENCES}

1. PV Sharma,dravyaguna vignan-2013, Chaukhambha Sanskrith Prathistan. (a) Sushruta, Sushruta Samhita,Ayurveda Tatva Sandeepika, hindi commentery, Chaukamba Samskruth Samsthana, Varanasi, 2012,Sutrasthana,39/7.

(b) Vagbhata,AshtangaHrudaya,Nirmala Hindi Commentery, Dr.Brahmananda
Tripati,Chaukambha Samsruth Pratishtana,Delhi, 2009, Chikitsa sthana,6/27. 1C Chunekar K C,Bhavaprakasha Nighantu, Chaukamba Bharati Academy, Varanasi, 2013 edition, 232,233,406 shloka

(d) Prof K R Shreekantha Murty,Sharngadhara Samhita, A treatise on Ayurveda, Chaukamba Orientalia Varanasi,2017 edition, ISBN-9788176371063,Uttarardha

Govind Das Sen, Bhaishajya Ratnavali, Netrarogachikitsa Prakaranam, Edn 13 , Chowkhamba Sanskrit Sansthan, Varanasi; 1997; 64:218

3. Acharya Basavaraju, Basava rajeeyam. Edn 1, vol 1, Chaukamba publications; 2005 $17: 148$

4. Acharya Sarangadhara, Sarangadhara Samhita. Edn 1, Vol1, Chaukhamba Sanskrit Sanstan, Varanasi 2001;9:66.

5. P. Pundareekaksharao, Ophthalmic uses of Boerhavia diffusa, (Punarnava) Review Int.J.of Herbal Medicine, E-ISSN- 2321-2187, 2016;4(2) : 05-09.

5(a) Pranati Nayak, MThirunavoukkarasu, A review of the plant Boerhaavia diffusa: its (a) Pras chemistry, pharmacology and therapeutical potential, The Journal of Phytopharmacology 2016; 5(SSN 2230-480XJPHYTO 2016; 5(2): 83-92March-
April(O) 2016,2): 83-92Online at:www.phytopharmajournal.com

6. Basu NK, Lal SB, Sharma SN. Investigations on Indianmedicinal plants. Q J Pharm Pharmacol 1947;20:38-42.

7. Mahesh AR, Kumar H, Ranganath MK, Raviraj AD. Detail study on Boerhaavia diffusa plant for its medicinal importance-A Review. Res J of Pharm Sci 2012;1(1):28-36

8. Awasthi LP, Verma HN. Boerhaavia Diffusa - A wild herb with potent biological and antimicrobial properties, J Department of Plant Pathology Narendra Dev University of Agriculture and Technology:Kumarganj, Faizabad, Uttar Pradesh, India

9. Thakur RS, Puri HS, Husain A. Major Medicinal Plants of India. Central Institute of Medicinaland Aromatic Plants (CIMAP), Lucknow:Uttar Pradesh, India;1989 p. 116.

10. Bhansali RR, Kumar A, Arya HC. In-vitro induction of adventitious shoots on stem Bhansali RR, Kumar A, Arya HC. In-vitro induction of advent
explants ofBoerhaavia diffusaL. J Current Sci 1978;47:551-2.

11. Shrivastava N, Padhya MA. "Punarnavine" profile in the regenerated roots of Boerhaavia diffusaL. from leaf segments. J Current Sci 1995;68:653-56.

12. Meena AK, Niranjan US, Yadav AK, Ajit K, Singh B, Kiran, Rao MM. A Quality Assessment of Boerhaavia Diffusa Linn. commonly known as 'Punarnava' plant. Int J of Pharmacognosy and Phytochemical Res 2010;2(1):25-8.

13. Santhosha D, Ramesh A, Prasad MS, Kumar DS, Kumar BP, Dhanalakshmi.Punarnavaa review, Res J of Pharm Biological and Chemical Sci 2011;2(4):427-35

14. Singh A, Eno EE, Quraish MA.Boerhavia Diffusa (Punarnava) root extract as green corrosion inhibitor for mild steel in hydrochloric acid solution:theoretical and electrochemical studies. Int J of Electrochemical Sci 2012;7:8659-75.

15. Apurba Sarkar APU, Asian Pac J Prop Biomed 2012 Sept 2(9) 673-678

16. SVVNSM lakshmi anti cataract potential of Boerhavia diffusa roots on galactose induced cataratogenesis, Indian journal of experimental biology, UST- 55, dec 2017, PP 838-844.)

17. Potential herbs used in ocular diseases (ISSN- 0975-1459) Journal of pharmaceutica science and research P.S Sandhu et al/ JPharm.sci and Res. Vol 3(4), 2011, 1127-1140

18. Suralkar AA, Verma AK, Kamble RD, Thayade GV (2012) pharmacological evaluation of anti histaminic activity of Beoehavia diffusa. In J Adv pharm Biol/Chem 1(4): 503-507

19. Bhowmik. D, Sampath KP, Srivastav. S, Paswan. S, Dutta AS, Traditional Indian herbs punarnava and its medical importance. Journal of Pharm and Phytochemistry 2012: 1(1) 59-65) - Kulkarni S K, Handbook of Experimental Pharmacology, J Vallabh Prakashan 2003: 03: 128-131

20. Itoozhi Unnikrishan Namboothitri A Unicentric interventional trial to assess the efficacy of Boerhavia diffusa juice extract through nasal drug delivery in the management of intra ocular pressure in chronic simple glaucoma, 18th Asia Pacific Ophthalmologist Annua Meeting, July 29-30, 2019, Melborne, Australia, Journal of clinical and experimental ophthalmology ISSN: $2155-9570$

21. Velmurugan V, Arunachalam G, Ravichandran V. Antibacterial activity of stem barks o Prosopis cineraria (Linn.) druce Archives of Applied Science Research. 2010; 2(4):147150.

22. Awasthi LP, Verma HN. Boerhaavia diffusa - A Wild Herb with Potent Biological and Antimicrobial Properties Cold Restraint Stress model, Asian Agri-History 2006; 10(1):55-68. b.

23. Rajkala S. Ramteke, Anup B. Thakar, Amiben H. Trivedi, and Panchakshari D. Patil Clinical efficacy of Gokshura-Punarnava Basti in the management of microalbuminuria in diabetes mellitus Ayu. 2012 Oct-Dec; 33(4): 537-541 Journal List, Ayu, v.33(4); OctDec 2012,PMC3665195. 